African Journal of Educational Studies in Mathematics and Sciences Vol. 6, 2008

\title{
Distance Learners' Perception of Learner Support Services
}

\begin{abstract}
Asante, 0.6
\section{Abstract}

Inadequate learner support has been identified as a major factor for dissatisfaction among students learning by the distance mode. The University of Education, Winneba (UEW), produces self instructional materials for its distance education students and in addition provides some learner support services. The study investigated UEW Distance Education (DE) students' perceived satisfaction with learner support services available to them. The study revealed that most distance education students had high perceived satisfaction with learner support services offered them. Differences in perceived satisfaction with specific learner support services were however observed. Most students' perceived satisfaction with tutorials and counselling services was high, but low for financial, library and study centre facilities and services. Significant differences were observed among the various study centres in respect of the DE students' perceived satisfaction with the learner support services provided for them.
\end{abstract}

Keywords: distance education students, learner support services, perceived satisfaction

\section{Introduction}

Systematic continuous learning opportunities for teachers can have a positive effect on their performance. According to Firestone and Pennel, (1993), such opportunities contribute to teachers' commitment by expanding their knowledge base, increasing skill variety, allowing the use of new techniques, providing insight to address new goals and content while reducing the endemic uncertainty of teaching.

In the pursuit of producing and maintaining highly qualified teachers for the Ghanaian schools, various forms of in-service training courses have been put in place for teachers after initial certification. Until the 2002/2003 academic year, certificated teachers in the country who had done three years of teaching qualified for study leave with pay if they wished to pursue further studies in education related courses at the tertiary level. This motivated most teachers to pursue further studies which resulted in very alarming proportions of teachers leaving the classrooms without corresponding replacement (Budu-Smith 2002). The Ghana Education Service, therefore, introduced a new study leave policy based on the quota system in 2003 to ensure that the classrooms were not deserted. For teachers who did not obtain study leave with pay, the availability of distance education programmes mounted for teachers by the Universities granted them the opportunity to study while working.

\footnotetext{
${ }^{6}$ Asante, O. is a lecturer at the Centre of Distance Education, in the Institute for Educational Development and Extension, at the University of Education, Winneba, Ghana.
} 
Studies in distance education practices show that there is hardly any distance education institution in the world that does not supplement its course materials with learner support as a way of ensuring persistence on, and success in the programme (International Extension College and Institute of Education, 1998). Although there are support services in place at the University of Education, Winneba, (UEW) Anamuah-Mensah (2002) observed that the drop-out rate in the university's distance education programme was high. He indicated that, the University of Education, Winneba, registered and matriculated 196 students on the B.Ed distance education programme which took off in 1997. Out of this number, 134 completed their courses, indicating a $31 \%$ drop-out rate of their initial enrolment. Though the diploma in basic education programme also registered 1,384 distance learners for its first batch, by December 2002, the researcher observed that this number had reduced to 1094, showing a loss of 290 students $(21 \%)$ who might have dropped out or become inactive. One might wonder why the centre for Distance Education in UEW recorded high percentage student drop-outs between the period of registration and completion. A study of the student handbook revealed that seven regional study centres had been located within selected colleges of education and the university campuses to provide learner support to meet the learning needs of UEW distance learners. The students voluntarily register at centres they would like to patronise.

Since the development of effective support services complements good learning materials to make a distance education programme achieve its objectives of supporting its clientele to be successful, one may ask how the distance learners perceive the available support services put in place for them in terms of meeting their learning needs. This is because it is one thing for distance education institutions to provide learner support services that they think would satisfy their students' learning needs and another thing for the students to have a similar perception given their peculiar circumstances. The desire to find out the distance learners' perceived satisfaction with available support services and their learner support needs spurred this study.

\section{Literature Review}

Distance education has been defined by the United States Distance Learning Association (USALA 2002) as teaching and learning situations in which the instructor and the learner are geographically separated and therefore rely on electronic devices and print materials for instructional delivery. While agreeing with the geographical separation of instructors and distance learners, Keegan (1990) notes that occasional meetings for didactic and socialisation purposes exist in distance education .In addition, distance learners are usually part-time students with work and family commitments suggesting that the time they can devote to study is limited (Hodgson 1993).

High travelling costs, long distance travels to regional study centres, lack of adequate reference books, lack of access to library facilities, and lack of urgency in setting up district study centres in all regions have been identified as problems encountered by students in the University College of Distance Education, Zimbabwe( Joshie 1999).In the light of this, Molefi (1998) intimates that, the success of students and the institution providing distance education depends not only on the quality of the learning materials or programmes produced but also upon the quality and scope of the academic and administrative support that is given. 
For effectiveness and efficiency, Owusu-Mensah (1998), from his comparative study, adds that a student support subsystem should be in place in any distance education programme to complement the course materials and management administration subsystems. He observed that at Makerere University in Uganda, external students did not enjoy the best of library services because most study centres did not have libraries and the few which had, did not have current books. Public libraries in Uganda were also not well equipped to be useful to the students. The students' best opportunity was to travel to the main university library since they could not borrow books through the post and this situation was a bother to many.

On the other hand, Distance learners in the University of Namibia could borrow books from the main library and return them on schedule while they had access to reference textbooks at the study centres. Prescribed textbooks were also made available at the university bookstore and students were encouraged to purchase them.

Distance learners have been found to be highly motivated when they had frequent contact with their instructors(Coldeway,Macrury,\&Spencer,1980). This is supported by Burge \& Howard(1990) who observed that the utilization of on-site facilitators who developed personal rapport with distance students and were familiar with equipment and course materials, increased students' satisfaction with courses.

It is observed from the literature that the issue of distance and peculiar learner characteristics call for well designed support systems to encourage persistence on distance education programmes. Such support should serve the intellectual, organisational and emotional needs of learners (Simpson, 1992).

\section{Research Questions}

1. What learner support services are available to UEW distance education students?

2. How do UEW distance education students perceive their satisfaction with learner support - tutorials, counselling, library facilities and services, student group interaction, study centres, assignment, assignment feedback and financial support in place for them?

\section{Method}

The study was a descriptive survey aimed at describing existing conditions during the conduct of the study. The study targeted distance education students of UEW who had spent a year or more on the university's Basic Education programme. The seven study centres patronized by these students were zoned to provide representative views from the northern, middle and southern sectors of Ghana. Five study centres out of a total of seven were purposefully selected from the three zones with a population of 861.The total sample for the study was 268. For each study centre, the students were stratified by gender and out of 488 males, 150 were sampled while 118 females were sampled from337 randomly to conform to estimates provided by Morgan and Krejcie (1970) which indicate that a population size of 850 should have a sample size of 265 , about $30 \%$ of the population.

Two main sets of data were used in the study. Documentary data in the form of the official DE student handbook of UEW which contained guidelines for student support. Study centres and other related learner support services and facilities are outlined in the 
handbook. Attendance registers for tutorials at the study centres provided data on active and non-active students. The second set of data was derived from a distance learners' support services questionnaire (DLSSQ) responded to by distance learners who had spent a year or more on the UEW DE programme.

The distance learners support services questionnaire was developed with ideas from related studies on distance education by Sam- Tagoe (2000) and Bame's (1993) study on teacher retention and motivation conducted in Ghana. Validation of the content was done by experts in distance education and experienced lecturers at the University of Cape coast and UEW. The DLSSQ contained a five-point likert-type scale which was the main scale of measurement for the distance learners' perceived satisfaction with their support facilities and services. The Cronbach alpha reliability of 0.82 was obtained for the Likert scale items with the help of the Statistical Package for Social Sciences computer package (SPSS). Section 'B' of the DLSSQ contained 14 open-and closed-ended items, which sought to ascertain the available learner support for UEW distance education students.

The data were run as frequencies, percentages and means. Items of the Likert-type scale were initially scored as ordinal level data. Mean scores on the Likert - type items for the 268 distance learners were determined and used to ascertain whether their perceived satisfaction with learner support was high or low. A mean score of 3.0 was used as the cut-off point to reduce the perception scores to nominal data and categorise respondents into those with high or low perceived satisfaction based on Kubiszyn and Bonich's (1984) assertion that "higher weights are associated with positive attitudes and lower weights with negative attitudes and as a rule a mean score of 3.0 is used". To ascertain any significant differences among the proportions of students of different study centres in terms of their perceived satisfaction with available learner support, the Chi-square test for differences in proportions was conducted.

\section{Results and Discussions}

The study revealed the available learner support structure of the UEW distance education programme and the students' perceived satisfaction with such support to confirm the assertion that there is hardly any distance education institution that does not provide learner support as a way of encouraging persistence on and success in its programme. (International Extension College and Institute of Education, 1998). The study revealed the following as constituting the learner-support structure of UEW:

- Study Centres

- Counselling/Face to face tutorials

- Face-to-face residential sessions

- Assignments/Assignments feedback

- Financial support

- Library facilities and services

- Student-group interactions

- Learner-tutor-interactions 
The students' perceived satisfaction with the specific learner support put in place for the DE programme is shown in Table 1.

Table 1 Students' Perceived Satisfaction with Specific Learner Support

\begin{tabular}{lcccccc}
\hline & \multicolumn{3}{c}{ Category of Perceived Satisfaction } & \multicolumn{2}{c}{ Low Perceived } & \multicolumn{2}{c}{$\begin{array}{c}\text { High Perceived } \\
\text { Satisfaction }\end{array}$} & \multicolumn{2}{c}{ Total } \\
Specific Learner Support & No & $\%$ & No & $\%$ & No & $\%$ \\
& 7 & 2.6 & 261 & 97.4 & 268 & 100 \\
& 32 & 11.9 & 236 & 88.1 & 268 & 100 \\
Tutorials & 218 & 81.3 & 50 & 18.7 & 268 & 100 \\
Counselling & 173 & 64.6 & 95 & 35.4 & 268 & 100 \\
Library & 197 & 73.5 & 71 & 26.5 & 268 & 100 \\
Student-Group Interaction & 118 & 44.0 & 150 & 56.0 & 268 & 100 \\
Study Centre & 240 & 89.6 & 28 & 10.4 & 268 & 100 \\
Assignments and feedback & & & & & &
\end{tabular}

The findings as in Table one show that majority of the students expressed high perceived satisfaction with tutorials (97.4\%) counselling (88.1\%) assignment and assignment feedback $(56.0 \%)$. However, most of them expressed low perceived satisfaction with available financial support $(89.6 \%)$ library support $(81.3 \%)$ study centres $(73.5 \%)$ and student group interaction $(64.5 \%)$.

Further investigations of the general impressions of male and female DE students about their learning facilities and services provided the information in Table 2

Table 2 Students' General Impression of Learning Facilities and Services

\begin{tabular}{lcccccc}
\hline & \multicolumn{2}{c}{ Respondents } & \multicolumn{3}{c}{ Total } \\
& Male & \multicolumn{2}{c}{ Female } & \multicolumn{3}{c}{ No. } \\
Responses & No. & $\%$ & No. & $\%$ & No \\
\hline Satisfied with facilities and services. & 96 & 64 & 68 & 57.6 & 164 & 61 \\
Dissatisfied with facilities and services. & 54 & 36 & 50 & 42.2 & 104 & 39 \\
\hline Total & 150 & 100 & 118 & 100 & 268 & 100 \\
\hline
\end{tabular}

The study revealed that generally, $61 \%$ of the respondents were satisfied with the available learning facilities and services while $39 \%$ were dissatisfied. The reasons given by the two groups of respondents for their satisfaction or dissatisfaction with available facilities and services confirm the strengths and weaknesses in the learner support structure of UEW. The dissatisfied 39\% respondents stated the following as reasons for expressing dissatisfaction.

- Difficulty in accessing financial support 
Distance Learners' Perception of Learner Support Services

Asante, 0.

- Libraries non-existent, far away or ill equipped

- Inadequate classroom accommodation for face-to-face tutorials and residential sessions

- Limited opportunities for monthly tutorials: a minimum of five and a maximum of seven contact sessions per course.

- High turnaround time for assignments: when time lapse between submission of assignments and return of tutor marked assignments goes beyond four weeks stipulated by the university.

- Limited student-tutor interaction

- Limited length of time for residential revision and examination: ten days

- Delays in supply of course books

The satisfied $61 \%$ DE students indicated the following as their reasons for expression of satisfaction with the learner support services:

- Flexible terms of fees payment: by installment

- Detailed, communicative and individualised course books

- Good quality face-to-face tutorials

- Good quality personal and academic counselling from study centre coordinators

- Helpful student handbook

The observation that $61 \%$ of the DE students demonstrated satisfaction with their learner support is quite encouraging but the problems enumerated by the dissatisfied $39 \%$ cannot be overlooked by distance education providers. Such problems have been identified by Kember (1989) and Woodley and Parlette (1983) as contributing to student drop-out in distance education.

Since the DE students of UEW patronised different study centres and enjoyed most of the learner support services there, their perceived satisfaction with available support services by centres was ascertained. Table 3 shows that a higher percentage of student respondents who patronised study centres at Tamale (72.8\%), Kumasi (64.6\%) and Winneba (60.9\%) had high perceived satisfaction with their learner support services. On the contrary, majority of the student respondents who patronised the Koforidua centre $(65.0 \%)$ and Hohoe centre (51.0\%) had low perceived satisfaction with their learner support. 
Table 3 Students' Perceived Satisfaction with Learner Support Services by Study Centres

\begin{tabular}{|c|c|c|c|c|c|c|c|}
\hline \multirow[b]{3}{*}{ Study Centre Patronised } & \multicolumn{4}{|c|}{ Category of Perceived Satisfaction } & & & \multirow[b]{3}{*}{$\chi^{2}$ Value } \\
\hline & \multicolumn{2}{|c|}{$\begin{array}{l}\text { Low Perceived } \\
\text { Satisfaction }\end{array}$} & \multicolumn{2}{|c|}{$\begin{array}{l}\text { High Perceived } \\
\text { Satisfaction }\end{array}$} & \multicolumn{2}{|c|}{ Total } & \\
\hline & No. & $\%$ & No. & $\%$ & No. & $\%$ & \\
\hline Tamale & 28 & 27.2 & 75 & 72.8 & 103 & 100 & \\
\hline Kumasi & 17 & 35.4 & 31 & 64.6 & 48 & 100 & \\
\hline Winneba & 18 & 39.1 & 28 & 60.9 & 46 & 100 & 15.101 \\
\hline Hohoe & 26 & 51.0 & 25 & 49.0 & 51 & 100 & \\
\hline Koforidua & 13 & 65.0 & 7 & 35.0 & 20 & 100 & \\
\hline Total & 102 & 38.1 & 166 & 61.9 & 268 & 100 & \\
\hline
\end{tabular}

Differences in proportions in terms of the students perceived satisfaction was further investigated to test the hypothesis that: "There is no significant difference among the proportions of students of different study centres in their perceived satisfaction with available learner support". Table 3 provides the details.

The Pearson Chi-square test for differences in proportions used to ascertain the significance of differences observed in the students' perceived satisfaction by centres provided the following results: $\chi^{2}(4, \mathrm{~N}=268)=15.101, \mathrm{p}=0.004$ with a critical ChiSquare value of 9.488 observed at 0.05 . The null hypothesis was rejected to establish the fact that the differences in perceived satisfaction with learner support at the different study centres were significant. Since the study centres have their peculiar characteristics, students who patronise such centres might have their peculiar needs and values likely to influence the way they perceived their available learner support services.

Another view of the situation is that differences exist in the quality and scope of the learner support services provided at the different study centres and such differences work against equal access and benefits for all the distance learners contrary to the South African Quality Criteria for Distance Education Learner Support (2002), which indicate among others the availability of satisfactory and cost-effective arrangements to meet learners' needs for physical facilities for study, tutorials and resource space as well as access to facilities like libraries and equipment necessary for successful learning.

The findings were generally consistent with those of other studies conducted in Ghana and elsewhere concerning learner support for distance learners (Burge \&Howard, 1990; Simpson, 1992; Owusu-Mensah, 1998; Molefi, 1998; Joshie, 1999).

\section{Conclusion}

The University of Education, Winneba recognises learner support as an integral part of its distance education programme. The overall high perceived satisfaction with available learner support services observed among most student respondents provides a positive signal for students' persistence and continuous patronage of UEW distance education programme. However, most DE students do not enjoy adequate financial, library and study centre support. Significant differences found among the proportions of students of 
Distance Learners' Perception of Learner Support Services

Asante, 0.

the different study centres in terms of their perceived satisfaction with their learner support services indicate discrimination in the provision of such support at various study centres.

It is recommended that the University of Education, Winneba, improves the facilities and services at the regional study centres giving special attention to Koforidua and Hohoe centres while locating new ones to provide easy access to learner support. Distribution of high quality staff, equipment and materials to various study centres should be equitable. To reduce turnaround time and improve student- tutor interaction at tutorial sessions, the number of tutors should be increased while large classes are reduced to manageable sizes. Relevant and easily accessible library facilities and services should be made available to the DE students. The University in partnership with other institutions and funding agencies can stock sections of existing libraries for the benefit of DE students. Online computer access to the University library should be arranged for DE students to utilize at their convenience.

The admissions office in collaboration with the Centre for Distance Education should provide pre- entry information on procedure for accessing the students' loan scheme. The flexible terms of fees payment should be maintained by the University with improved strategies for collection. The Ghana Education Service should adopt a pragmatic approach in providing early financial and material support to teachers learning by DE mode as compensation for the choice of combining work and studies. Adequate learner support remains an integral part of any DE programme to ensure student persistence and completion of programmes. The University of Education and the Ghana Education Service should therefore leave no stone unturned to support DE students adequately.

\section{References}

Anamuah-Mensah, J. (2002) Ensuring effective delivery of distance education in Ghana: The role of learner support. Paper Presented at the $2^{\text {nd }}$ African Convention of Principals at GIMPA, Accra (August $18^{\text {th }}-22^{\text {nd }}$ ).

Bame, K. N. (1991). Teacher motivation and retention in Ghana. Accra: Ghana Universities Press.

Budu-Smith, J. (2002, June 21).G.E.S.can't cope with alarming rate of teachers' study leave. Daily Guide (No.668), p.2.

Burge, E. J. \& Howard, J.L. (1990). Audio-conferencing in graduate education: A case study. The American journal of distance education 4 (2), 3-13

Coldeway, D. O., MacRury, K., \& Spencer, R. (1980). Distance education from the learner's perspective: The results of tracking at Athabasca University. Edmonton: Athabasca University.

Firestone, W. A. \& Pennel, J. R. (1993). Teacher commitment working conditions and differential incentive policies. Review of Educational Research, 63 (4), 489-490.

Hodgson, B. (1993). Key terms and issues in open and distance learning. London: Kogan Page Limited. 
International Extension College and Institute of Education (1998). Distance education for development. Module 3: Learner support in distance education. MA Units. London: University of London.

Joshie, I. (1999). Scenario of distance education in African countries: Case studies. Retrieved December 15, 2002, from http://www.orbicom.ca/in_focus,/columns/en/archives/1999_aout.html

Keagan, D. (1990). Foundations of distance education $\left(2^{\text {nd }} \mathrm{ed}\right)$ London: Routledge.

Kember, D. (1989). A longitudinal process mode of dropouts from distance education. Journal of Higher Education, 60 (3), 278-301

Kubiszyn, T., \& Bonich, G. (1984). Educational testing and measurement. London: Scott, $\quad$ Foresman and Company.

Molefi, F. (1998). Support services for distance education students at the department of non-formal. A paper presented at the distance education workshop for Setswana Part- time Writers. Retrieved December 15, 2002, from http://www.saide.org.za/worldbank/management/teaching/m37 abot.html

Morgan, D. W. \& Krejcie, R. V. (1970)._Determining sample size for research activities, education and psychological measurement. London: Sage Publications.

Owusu-Mensah, F. (1998). The provision of student support services in distance education in three different contexts: implications for University College of Education of Winneba. An unpublished MA dissertation. University of London.

Sam-Tagoe, J. (2000).Teachers perception and needs of distance education programme in Ghana. An Unpublished M.phil Thesis. University of Cape Coast.

Simpson, O. (1992).Meeting the needs of the learner. In Distance education for development module 3: Learner support in distance education. MA Units. (Pp329). London: International Extension College and Institute of Education, University of London.

United States Distance Learning Association (2002). What is distance education? Retrieved December 15, 2002 from California distance learning project resources, distance learning information site: http://www/ed/ponline.or/d/info/cd/p1/distance/what is.html.

Woodley, A. \& Parlette, M. (1983). Student drop-out. Teaching at a Distance, 24, 2-23. 